\title{
Cienoša komunikācija audzināšanā kā bērncentrētas bērnības arhitektūra
}

\section{Dignified Communication in Parenting as the Architecture of Child-Centred Childhood}

\author{
Dace Medne
}

\begin{abstract}
Mūsdienās bērna un bērnības vērtība gan no personības attīstības, gan kultūras, gan politiski ekonomiskā viedokḷa ir aktuāla. Bērnība ir sociāla struktūra, kurā veidojas personība, arī audzināšanai ǵimenē raksturīga nepārtrauktība un ilglaicīgums, un tā ir būtisks nosacījums personības tapšanā. Tāpēc jautājumi, kas saistīti ar bērnības un audzināšanas būtību postmodernismā, nezaudē savu aktualitāti. Postmodernisma laiktelpai raksturīgais domāšanas plurālisms veicina bērncentrētas pieejas un audzināšanas liberalizācijas tendences ǵimenē, tas pedagoǵijai nozīmē citādāku teorētisko un prakses nostādņu meklējumus. Rakstā tiek aktualizēta bērncentrētas audzināšanas izpētes perspektīva ǵimenē, kuras pamatu veido cienošas komunikācijas pamatprincipi, tādējādi veidojot bērnības saturu.
\end{abstract}

Atslēgvārdi: audzināšana ǵimenē, bērn̄iba, bērncentrēta pieeja, cienoša komunikācija.

\section{Ievads}

Bērnības analīzes aktualitāti nosaka pieaugošās sociālpolitiskās nostādnes bērnu tiesību jomā, tādējādi aizskarot arī bērna un bērnības jautājumus audzināšanas kontekstā. Varētu pat uzskatīt, ka mūsdienu sociālpolitiskā situācija provocē domāt par bērnību, jo gan zinātniskajās diskusijās, gan ordinārajā praksē, gan mediju telpā tiek aktīvi diskutēts par bērnības saturu un bērna pozīciju tajā, biežāk no bērnu tiesību aspekta, retāk pieskaroties audzināšanas jautājumiem. Tādējādi bērnības diskurss kḷūst par mūsdienu subjekta pašapziņas konstruējošu sākumu. Šĩ temata popularitāte rosina uzdot jautājumus, kāpēc mūsdienu cilvēkam ir tik svarīgi sevi atrast bērnības diskursā, vai tā ir kārtējā "pedagoǵiskā mode" vai atbild par daudz dziḷākiem subjekta veidošanās nosacījumiem. Pēdējos gados iezīmējas jauna teorētiskā bērnības izpratne, kas rosina pētniekus pārskatīt "bērna" statusa sociālo un individuālo uztveri, audzināšanas mērķus un uzdevumus. Šīs izpratnes maiņas rezultātā, no vienas puses, tiek mainīts izpētes fokuss no pedagoǵiskās jābūtības uz bērna attīstības vajadzību izpratni viņa ikdienas pieredzes konstruēšanai. No otras puses, ikdienā aizvien biežāk tiek diskutēts par bērnu agresīvu uzvedību, kas rada pamatotus draudus savai, citu izglītojamo un izglītības iestādes darbinieku veselībai, dzīvībai vai drošībai. Tāpat aktīvi tiek izcelti dažādi mākslīgi veidoti sociālie fenomeni, piemēram, "kristāliskie", "indigo", tiek uzskatīts, ka pēc 2012. gada dzimušie ir "varavīksnes" bērni, kas dzimuši kristāliskajiem un indigo bērniem. Šajās diskusijās jautājums par 
ǵimeni un audzināšanu tajā paliek otrajā plānā vai vispār netiek izskatīts. Tādi sociāli fenomeni kā pedagoǵiskā "mode" nav nejauši, tos nedrīkst ignorēt, uzsver Volfgangs Bergmans (Wolfgang Bergmann) ${ }^{1}$. Emija Piklere (Emmi Pikler) šo fenomenu nosauc par vecāku lepnuma maldiem, jo viṇi nevis meklē cēloņus bērnu uzvedībai, bet lepni definē, ka viņu bērni ir īpašāki ${ }^{2}$ Katra aktuālā pedagoǵiskā "mode" novirza uzmanību no problēmas, nekritiski padarot kādu izredzētu sabiedrības dalı par īpašu. Šāda audzināšana ikdienā ieskicē risku, jo iezīmējas tendence akcentēt uzvedības problēmu kā īpaši izredzētas sabiedrības daḷas fenomenu, nevis koncentrēties uz kompetentu pedagoǵisku risinājumu meklējumiem, kas, apmierinot bērnu vajadzības, konstruētu bērnību. Šādi fokusējoties uz problēmu, rezultāts ir "vainīgā" vai "laimīgā" atrašana, nevis produktīvs pedagoǵisku risinājumu un resursu meklējums audzināšanas perspektīvai, uzsver Dace Medne ${ }^{3}$. Johanness Švārte (Johannes Schwarte) uzsver, ka mūsdienu bērns, kuram ir personības problēmas un ar kuru problēmas ir gan vecākiem, gan skolotājiem, ir komunikācijas problēmu sekas ǵimenē $\overline{ }^{4}$. Mūsdienās daudz tiek diskutēts par to, ka vecākiem nav pedagoǵiskās izglītības, tāpēc viṇi nezina audzināšanas likumsakarības un paṇēmienus un attaisno šādu situāciju. To analizējot, Klauss Šnēvinds (Klaus Schneewind) un Beāte Bēmerte (Beathe Böhmert) uzsver: nav attaisnojams viedoklis, ka ǵenētiski argumenti pedagoǵiski nevarīgos vecākus atbrīvo no atbildības par audzināšanu. Š́ s̄i situācija audzināšanā raksturojama kā "mulsums audzināšanā" pārvarētu un pārvērstu pedagogiski pamatotā rīcībā (pieaugušā rīcībspējā), būtiski analizēt audzināšanas un bērnības mijsakarības mūsdienu postmodernisma situācijā.

Problēmas aktualitāte rosina jautājumu - kāda audzināšana apmierina gan bērna, gan pieaugušo vajadzības un konstruē bērncentrētu bērnību?

\section{Bērncentrēta bērnība - diskusiju krustugunīs}

Mūsdienās bērnības eksplikācija atklājas divos diskursos, veidojot aktuālas dimensijas, kas nozīmīgas cilvēka dzīvesdarbības laiktelpā un mūsdienu cilvēka pašnoteikšanās procesā. Šie diskursi ne vienmēr ir pēctecīgi un bieži veido polaritātes. Piemēram, bērnība tiek saprasta kā dzīves nākotnes potenciāls, bet tās saturs tiek interpretēts kā tagadnes attīstības pretrunu pārvarēšana no nākotnes projektēšanas pozīcijas. Šāda bērnības interpretācija veido socioloǵisko, politisko

1 W. Bergmann, Gute Autorität. Grundsätze einer zeitgemässen Erziehung, Weinheim und Basel, Beltz Verlag, 2006, S. 10-205.

2 E. Pikler, Friedliche Babys - zufriedene Mütter, Freiburg, Basel, Wien, fgb, 2007, S. 42-131.

3 D. Medne, Audzināšana ğimenē Latvijas transformāciju sabiedrībā (Family upbringing in the transformative society of Latvia), promocijas darbs pedagogijā (Dissertation in Pedagogy), Rīga, LU, 2010, 4. lpp.

4 J. Schwarte, Der Werdende Mensch. Persönlichkeitsentwicklung und Gesellschaft heute, Wiesenbaden, Westdeutsche Verlag, 2002, S. 525-544.

5 K. Schneewind and B. Böhmert, Kinder im Grundschulalter kompetent erziehen. Der indirektive Elterncoach "Freiheit in Grenzen", Bern, Verlag Hans Huber, 2008, S. 44.

6 R. Reichenbach, Postmoderne und postpostmoderne Pädagogik. Philosophie der Bildung und Erziehung, Stuttgart, W. Kohlhammer, 2007, S. 218-238. 
disciplīnu saturu. Otrs diskurss vadošo akcentu bērnības izpratnē liek uz bērnību kā avotu, sākumu, saknēm, pamatu, kā eksistences veida atrašanu adekvātai tagadnes izpratnei. Šķietamās diskursu pretrunas ietver jēgas raksturu: tā ir sasaistes veidošana starp pagātni un tagadni, tagadni un nākotni ontoǵenēzē, sociālajā projektēšanā (bērni kā resurss), paaudžu attiecībās - kā attiecību veidošana jeb komunikācija.

Bērnības izpratnes attīstība notiek pieaugušo pasaulē un tiek skatīta kā pieaugušo un bērnu komunikācijas rezultāts. Jau D. Elkoņins (Даниил Элконин) apgalvoja, ka neeksistē sistēma "bērni un sabiedrība", bet ir sistēma "bērni sabiedrībā" . Bērna tēla konstruēšanai un bērnības satura specifikas izpratnei bija nepieciešams ilgs pieaugušā cilvēka sava Es izpratnes evolūcijas periods. 20. gadsimta sākumā aizsākas bērna kā īpašas kultūras vērtības pozicionēšana, kas saistîta ar cerībām uz nākotnes progresu. Ekonomiskās situācijas uzlabošanās kopā ar šo kultūras vērtības manifestēšanos sociālajā laukā nostiprināja divas idejas - bērnfokusētu un bērncentrētu ideju. Termini ir problemātiski, jo tos visbiežāk izmanto bez analīzes un kā sinonīmus.

Ja bērna vajadzības tiek interpretētas no pieaugušā pozīcijas, tad tiek runāts par bērnfokusētu pieeju, kur pieaugušie fokusējas uz bērna vajadzībām savas izpratnes ietvaros. Pieaugušie, kas kādreiz paši bija bērni, drīz vien aizmirst bērnību un to, kas bērnam bija vajadzīgs, tādējādi attālinoties no bērnu subkultūras, jo pieaugušajiem var būt grūtības "iegūt nepieciešamo attālumu līdz bērniem un bērnību" ". Šì atšksirība veidojas no pieaugušo pieņēmumiem par to, kas ir bērni un bērnība ${ }^{9}$. Šāda pieaugušo pozīcija tiek definēta kā dominantes kultūra, kur pieaugušie nosaka, kas bērnam vajadzīgs. Ja cilvēks izaug dominantes kultūrā, no šīs audzināšanas rodas daudz vardarbības, kas savukārt nostiprina šādu pasaules redzējumu tālāk ${ }^{10}$. Šis Maršala B. Rozenberga (Marshall B. Rosenberg) apgalvojums varētu teorētiski pamatot bērnu agresivitāti. Dominēšanas apstākḷıs ir skaidri jautājumi, ko otrs dara nepareizi, kuram ir taisnība, tas nozīmē, ka tas ir atklāts kaujas lauks un šāda situācija paredz tikai divas iespējas: sacelšanos vai pakḷaušanu, tieši tāpēc cilvēki dominantes kultūrā vienmēr

- $\quad$ zina, kas ir pareizi un kas nepareizi,

- analizē,

- kritizēe,

- interpretē,

- ir pārliecināti, ka zina, kas ar citiem nav kārtībā,

- vērtē, slavē un veido mērauklas,

- draud ar sodiem,

7 Д. Элконин, Психологя игры, Москва, ВЛАДОС, 1999, с. 176-184.

8 A. Solberg, 'The Challenge in Child Research from "Being" to "Doing", , in: J. Brannenand M. O'Brien (ed.), Children in Families: Research and Policy, London, Falmer Press, 1996, pp. 53-65.

9 B. Thorne, Gender Play: Girlsand Boys in School, Buckingham: Open University Press, 1993, p. 12.

${ }^{10}$ M. B. Rosenberg, Konfliktelösen durch Gewaltfreie Kommunikation. Ein Gespräch mit Gabriele Seils, Freiburg, Herder Verlag, 2004, S. 22. 
- koncentrē uzmanību uz noteikumiem un normām,

- ir pārliecināti, ka viņiem vienmēr ir taisnība,

- meklē vainīgo ${ }^{11}$.

Savukārt M. B. Rozenbergs uzsver, ka dominantes kultūrai raksturīga atsvešināta, neempātiska, respektīvi, komunikāciju bloķējoša, valoda aizspriedumu, diskriminējošu apgalvojumu, negatīvu un/vai nereālu gaidu un spiediena formā. Pie komunikācijas blokāžu izraisītājiem autors pieskaita

- morālos spriedumus un nonievāšanu,

- analīzes/diagnozes/interpretācijas,

- vispārinājumus,

- atbildības noliegšanu,

- prasību izvirzišsanu un draudēšanu ar sodiem,

- vainošanu,

- kaunināšanu / kauna izjūtas veicināšanu ${ }^{12}$.

Aktīvi atmetot šīs blokādes un izmantojot četru soḷu modeli, uzmanība apzināti tiek pievērsta tam, kādas ir cilvēka patiesās vajadzības; saskaņā ar kurām vērtībām viṇi vēlas rīkoties un kā cilvēki rūpējas par to, lai viṇu vajadzības tiktu apmierinātas, ievērojot citu vajadzības ${ }^{13}$. Tâpēc, lai mazinātu dominantes kultūras iespējamās sekas, pieaugušajiem būtiski atteikties no ierastā pien̦ēmuma, ka pieaugušo zināšanas ir pārākas par bērnu zināšanām ${ }^{14}$. Deivids Čeimberlens (David Chamberlain) vispārina šo apgalvojumu, uzsverot, ka pieaugušo tradicionālie uzskati par bērniem ir maldīgi, jo bērni nav vienkārši radījumi, viņi ir komplicēt i-subjekti ar plašu domāšanu ${ }^{15}$.

Savukārt izpratne, kas saistīta ar konkrēta bērna attīstības vajadzību izprašanu un apmierināšanu, ir bērncentrēta pieeja. Bērncentrēta audzināšana ir sistemātiska komunikācija, kurā ir partnerība, cieņa, tiek ievērotas katra vērtības un izvēles, atbalsts ${ }^{16}$. Bērncentrēta pieeja nozīmē, ka komunikācija ar bērnu tiek veidota no

${ }^{11}$ T. Heidegger and Wolf T., Von der Dominanz zur Empathie. Eine a-moralische Verführung in eine neue Kultur, 2009. Pieejams: https://www.zegg.de/images/reader/ZEGG-Reader2009.pdf.

${ }^{12}$ M. B. Rosenberg, Konflikte lösen durch Gewaltfreie Kommunikation. Ein Gespräch mit Gabriele Seils, Freiburg, HerderVerlag, 2004, S. 20.

13 Ibid, S. 22.

${ }^{14}$ P. Alderson and C. Goodey, 'Research with Disabled Children: How Useful is Child Centred Ethics?', Children and Society, vol. 10, No. 2., 1996, p. 108.

15 D. Chamberlain, The Mind of Your Newborn Baby, Berkeley California, North Atlantic Book, 1998.

${ }^{16}$ C. J. Dunst and C. M. Trivette, and D. W. Hamby, 'Metaanalysis of family-centered help giving practices research', Mental Retardation and Developmental Disabilities Research Reviews, vol. 13, 2007, pp. 370-378. 
bērna pozīcijas ${ }^{17}$. Bērncentrēta audzināšana tiek skatīta divās dimensijās, pirmkārt, kā griba (kādas ir bērna attīstības vajadzības) un intereses (kas jādara, lai apmierinātu bērna vajadzības $)^{18}$. Tātad bērncentrētas audzināšanas pamatā ir ideja par bērnu kā līdztiesīgu subjektu, kurš ir līdztiesīgs ar citiem ǵimenes locekl̦iem - viṇa vajadzības ir tikpat svarīgas kā pieaugušo ǵimenes locekḷu vajadzības. Un bērnu vajadzības, vecāku vajadzības un savstarpējās komunikācijas veids ir noteicošie aspekti, ka ir bērncentrētas audzināšanas pamatā.

Tomēr, analizējot bērncentrētu audzināšanu ordinārajā praksē, tiek uzsvērts: kaut gan jēdziens "bērncentrēta audzināšana" ǵimenē turpina apliecināt savu efektivitāti, realitātē tai raksturīga "lēna ieviešana"19.

\section{Audzināšana kā komunikācija}

Moderno sabiedrību raksturo nevis cilvēki, valstis vai lietas, bet gan komunikācija ${ }^{20}$. Edvards T. Holls (Edward T. Hall) uzsver, ka komunikācija ir kultūras būtība un patiesībā pašas dzīves būtība ${ }^{21}$. Realitāte ir nevis kaut kas, ko cilvēki manto, bet tas, ko paši rada, tā ir parādība, kas eksistē, pateicoties cilvēku komunikācijas spējām $^{22}$. Ar komunikāciju tiek veidota jēga, interiorizētas vērtības ${ }^{23}$, savukārt Ausma Špona uzsver, ka audzināšanas mērķis ir sekmēt attieksmju pilnveidošanos ${ }^{24}$. Tieši tāpēc komunikācija un audzināšana ir cieši saistītas un kḷūst viena par otras izpausmes veidu, proti, komunikācija ğimenē nosaka audzināšanas saturu. Sociālās vides konteksts, visvairāk - audzināšanas konteksts ir cilvēka dzīvesdarbības pozīcijas un personības virzības pamatnosacījums. Atsaucība un prasības attiecībās ar bērnu atspoguḷo pieaugušo uzskatus par audzināšanu, tās izpaužas viṇu komunikācijas stilā un emocionalitātê ${ }^{25}$. Jau Urijs Bronfenbrenners (Urie Bronfenbrenner) ir akcentējis

${ }^{17}$ Framework for the Assessment of Children in Need and their Families. Department of Health Department for Education and Employment Home Office. London The Stationery Office, 2000. Pieejams: http://webarchive.nationalarchives.gov.uk/20130401151715/https:/ www.education.gov.uk/publications/eOrderingDownload/Framework $\% 20$ for $\% 20$ the $\% 20$ assessment $\% 20$ of $\% 20$ children $\% 20$ in $\% 20$ need $\% 20$ and $\% 20$ their $\% 20$ families.pdf (accessed 23 February 2016).

18 D. Cooper, 'More law and more rights: will children benefit?', Child and Family Social Work, vol. 3, 1998, pp. 77-86.

${ }^{19}$ E. Crais and V. Roy and K. Free, 'Parents' and Professionals' Perceptions of the Implementation of Family-Centred Practicesin Child Assessments', American Journal of Speech-Language Pathology, vol. 15, 2006, pp. 365-377.

20 Th. Kurtz, 'Erziehung, Kommunikation, Person. Zur Stellung des Erziehungssystems in einem besonderen Quartettgesellschaftlicher Runktionen', in: Ehrenspeck Y., Lenzen D. (ed), Beobachtungen des Erziehungssystems. Systemtheoretische Perspektiven, Wiesenbaden, GWV Fachverlage GmbH, 2006, p. 113.

${ }_{21}$ E. T. Hall, The Hidden Dimension, USA, Anchor Books, 1990, pp. 3-4.

22 Dž. Rifkins, Jaunās ekonomikas laikmets, Rīga, Jumava, 2004, 173. lpp.

23 J. Fiske, Introduction to communication studies, London, Taylor \& Francis Group, $2^{\text {nd }}$ edition, 1990. Available from E-Book Library (accessed 24 February 2016).

${ }^{24}$ A. Špona, Audzināšanas process teorijā un praksēe, Rīga, RaKa, 2006, 91.-144. lpp.

25 D. Baumrind, Parental disciplinary patterns and social competence in child, Youth and Society, vol. 9, 1978, pp. 239-276. 
to, ka šo līdztiesisko pieeju nodrošina sadarbība gan ǵimenē, gan citās sociālajās institūcijās ${ }^{26}$. Mūsdienās emocionālā piesaiste tiek pamatota klīniskos smadzeņu pētījumos. Daniels Sīgels (Daniel J. Siegel) to sauc par neirobiologisko starppersonu pieredzi. Analizējot savstarpējo attiecību nozīmi bērna attīstībā, D. Sīgels uzsver, ka bērna smadzenēm sociālā vide sniedz svarīgāko pieredzi un nosaka, kādi gēni izpaudīsies. Gēni nosaka, kā neironi sasaistīsies cits ar citu, veidojot neironu cel̦us, kas nodrošina kognitīvo darbību ${ }^{27}$. Brūss Perijs (Bruce D. Perry) uzsver būtisku saistību starp vecāku pieredzi un bērnu pieredzi, kuras nosaka smadzeñu darbība, neironu celiiem pieaugušā smadzenēs, kas veido un uztur emocionālās attiecības ar bērnu, ir izšķiroša nozīme bērnam, jo šī pieredze noteiks, kā bērns spēs veidot intīmas un emocionāli veselīgas attiecības visu savu dzīvi ${ }^{28}$.

Komunikācija gimenē var tikt realizēta gan pozitīvajā (cienošā), gan negatīvajā (refleksīvajā) komunikācijas dimensijā. Lai attieksmes pilnveidotu, nozīmīgs ir cienošs komunikācijas process. Šādā izpratnē audzināšanas procesa realizāciju praksē raksturo divi aspekti - kā pieaugušie atpazīst bērnu vajadzības un kāda ir atsaucība uz tām, kā arī prasību atbilstība. Tieši paaudžu komunikācija ǵimenē nosaka, vai bērns interiorizē vecāku vērtības un kādas attieksmes, paradumus un uzvedības model̦us veido. Audzināšana ir vecāku komunikācija ar bērnu/-iem ikdienā, un vecāki ir tie, kas uzṇemas atbildību par komunikācijas formu un saturu. Tātad attieksmju pilnveidošanos nosaka komunikācija (kā vecāki komunicē ar bērnu), un tādējādi komunikācija audzināšanā kā attieksmju rosinātāja iegūst svarīgu nozīmi, jo veido personīgi svarīgas bērna vērtības.

\section{Cienošas komunikācijas būtība}

Komunikācijas modeli, kura pamatā ir vajadzības, to apmierinājums vai neapmierinājums, sauc par nevardarbīgās komunikācijas modeli, kuru M. Rozenbergs izveidoja 20. gadsimta 60. gados. Mūsdienās tiek lietots jēdziens "cienošas komunikācijas modelis". Šo jēdzienu ieviesa M. B. Rozenberga sekotāji, jo jēdzieni "cienoša komunikācija" un "nevardarbīga komunikācija" savā nozīmē būtiski neatšķiras. Apzīmējums "cienoša komunikācija” skaidrāk izsaka būtību, uz ko šis modelis attiecas, jo ideja ietver ne tikai nevardarbīgu konfliktu risināšanu, vardarbības prevenciju un vardarbības neesamību, bet arī galvenokārt savstarpēju atzīšanu, cieņu un empātiju, tādējādi nodrošinot stabilus kontaktus, sadarbību un patiesu emocionālo saikni $^{29}$. Cienoša komunikācija ir veids, kur, tā vietā, lai nosodītu citus vai vērtētu to, kādi citi ir vai ko viņi dara nepareizi, tiek runāts par to, ko paši uztver, jūt un kādas

${ }^{26}$ U. Bronfenbrenner, Making Human Beings Human: Bioecological Perspectives on Human Development, USA, Sage Publications, 2004.

27 D. J. Siegel, The Developing Mind: How Relationships and the Brain Interact to Shape Who We Are, New York, Guilford, 1999.

${ }^{28}$ B. D. Perry, 'The neurodevelopmental impact of violence in childhood', in: D. Schetky and E. Benedek (ed.), Textbook of child and adolescent forensic psychiatry, Washington DC, American Psychiatric Press, 2001, pp. 221-238.

${ }_{29}$ M. Müller, Wertschätzende Kommunikationin der Grundschule: Einerlebnis-und sprach orientiertes Handbuch in neun Modulen Taschenbuch, Create Space Independent Publishing Platform, 2016. 
ir pašu vajadzības ${ }^{30}$. Cienošas komunikācijas mērķis ir cilvēku savstarpējā sapratne, cieņa un atbalsts. Cieņa šajā gadījumā nozīmē nevis slavēt vai redzēt tikai pozitīvo, bet gan saprast savas un citu cilvēku vajadzības un izjūtas. Cienoša komunikācija mūsdienās ir pieprasīta sociālā prasme, lai pašnoteikti un efektīvi varētu darboties dažādās grupās, tai skaitā ǵimenē. Cienoša komunikācija nozīmē ko vairāk nekā tikai prasmi runāt: tā ir rīcība, kas ir apzināta, skaidra, atvērta, nevardarbīga un cienoša komunikācija, kas pamatojas uz empātiju. No vienas puses, pie cienošas komunikācijas pieder aktīvas klausīšanās un perspektīvu maiņas prasme, kā arī empātijas spēja, no otras puses, tai nepieciešama sadarbība, līdzdalība un godīgums lemšanas procesos, kā arī aktīva atbalsta kultūra ${ }^{31}$. Ar cienošo komunikāciju īpaši tiek stiprinātas divas sociālās prasmes: iejūtīga, skaidra un atvērta attieksme pret sevi un pret citiem. No tā izriet divi veidi, kā paust iejušanās prasmi:

- $\quad$ pašempātija (iejūtīga izturēšanās pašam pret sevi): savu izjūtu, vajadzību un lūgumu pazīšana, uzticēšanās sev;

- empātija pret citiem (iejūtīga izturēšanās pret citiem): citu izjūtu, vajadzību un lūgumu uztveršana, cienīšana un līdzjušana viņiem, atbalsts, viņiem apmierinot savas vajadzības ${ }^{32}$.

M. Rozenbergs izveidoja četru soḷu modeli iejūtīgai, skaidrai un atvērtai valodai. Četru soḷu model̦a pamata $\bar{a}^{33}$, atšķirīibā no fantāzijām un aizspriedumiem vai neskaidrām vai nereālām gaidām attiecībā uz kādu situāciju, ir novēroti fakti. M. B. Rozenbergs šo daļu sauc par novērošanu. Novērojumi ir izjūtu un vajadzību izraisītāji. Izjūtas un vajadzības kaut ko liecina par novērojumu nozīmi pašam cilvēkam vai citiem. Kad vārdus izmanto, lai pārspīlētu, tie izraisa vēlmi aizstāvēties, nevis līdzpārdzīvojumu ${ }^{34}$.

Skaidra novērojumu valoda ir valoda, kura nesatur morālus vērtējumus:

- $\quad$ var novērot tikai konkrētu rīcību, bet ne vispārinājumus, un tāpēc būtu jāizvairās no vārdiem "vienmēr", "nekad", "katrreiz" un "gandrīz nemaz";

- vēstījumi “es" formā otram palīdzēs situācijas novērtējumu neuztvert kā apvainojumu;

- novērojumus nevajadzētu jaukt ar morāliem spriedumiem, jo tad otrs dzirdēs galvenokārt to, ko viņš ir izdarījis nepareizi.

${ }^{30}$ M. Müller, Wertschätzende Kommunikationin der Grundschule: Einerlebnis-und sprach orientiertes Handbuch in neun Modulen Taschenbuch, Create Space Independent Publishing Platform, 2016.

${ }^{31}$ M. Müller, Wertschätzende Kommunikationin der Grundschule: Einerlebnis-und sprach orientiertes Handbuch in neun Modulen Taschenbuch, Create Space Independent Publishing Platform, 2016.

${ }^{32}$ Ibid.

${ }^{33}$ M. B. Rosenberg, Gewaltfreie Kommunikation. EineSprachedesLebens, Paderborn, Junfermann, 2008.

${ }_{34}$ М. Розенберг, Язык жизни. Ненасильственное общение, Киев, София, 2009. 
Nākamajā solī svarīgi apzināties savas izjūtas un izteikt tās, nevainojot citus:

- citu rīcība vai domas izraisa izjūtas, taču tās nav izjūtu cēlonis. Cilvēka patīkamo un nepatīkamo izjūtu cēlonis ir apmierinātas un neapmierinātas vajadzības;

- $\quad$ izjūtas ir vērtīga ķermeņa informācija, kas kalpo par orientieri (kas ķermenim vajadzīgs?) un rīcības aktivizēšanai (kā rūpēties par savām vajadzībām?);

- cilvēki uzņemas atbildību par savām izjūtām un izsaka tās citiem saprotamā veidā un bez apvainojuma.

Ir svarīgi valodā atpazìt atškirīību starp izjūtām un domām. Jau formulētajā valodā ir skaidrs, vai tiek izteiktas izjūtas vai interpretācijas, respektīvi, netieši apvainojumi. Netiešie apvainojumi veidojas situācijā,

- $\quad$ kad varētu būt kāds darītājs, piemēram, "es jūtos izmantots", "kāds - darītājs - mani izmanto";

- kad citu rīcību uzskatām par savu izjūtu cēloni, piemēram, "es dusmojos, jo tu mani esi aizmirsis" - rodas iespaids, ka izjūtu ir izraisījis otrs. Veiksmīgāks formulējums ir "es dusmojos, jo man vajadzīga drošība";

- $\quad$ kad tiek izteikti salīdzinājumi vai vērtējumi, piemēram, "es jūtos kā zilonis trauku veikalā”. Tas ir ļoti nenoteikts apraksts un ātri var tikt sadzirdēts kā netiešs pārmetums.

Visām izjūtām ir jēga, respektīvi, tās ir jēgpilna ķermeņa informācija. Tāpēc ir svarīgi atvēlēt laiku tam, lai uztvertu un novērotu savas izjūtas, lai atpazìtu un nosauktu tās.

Cilvēku veselība, labizjūta, dzīvesprieks lielā mērā ir atkarīgi no tā, vai viṇu vajadzības ir apmierinātas. Agresīva rīcība, diskriminēšana, mobings un aizspriedumi ir neapmierinātu vajadzību izpausme. Ja cilvēki prot saskatīt un cienīt savas un citu cilvēku vajadzības, tad konfliktos izdodas atrast konstruktīvas stratēgijas un risinājumus. Vajadzības atšksiras atkarībā no tā, kādas stratēgijas cilvēki izmanto, lai tās apmierinātu. Visiem cilvēkiem ir vienādas vajadzības, taču stratēgijas, kā viṇi tās apmierina, ir l̦oti atšķirīgas. Vajadzību apmierināšana nav piesaistīta vienai noteiktai stratēgijai (konkrētai personai, vietai, laikam un rīcībai vai objektam). Ir bezgalīgi daudz stratēǵiju. Vajadzības ir universālas, proti, visiem cilvēkiem ir vienādas vajadzības. Atpazīstot un izsakot tās, izdodas izveidot izpratni un emocionālo saikni ${ }^{35}$.

Kad cilvēki apzinās savas izjūtas un vajadzības, vinini vēlas, lai tiktu sadzirdētas vinu vajadzības. Jo šajā gadījumā runa ir ne tikai par to, lai iegūtu skaidrību par kādu situāciju un to saprastu, bet arī par to, lai rīkotos, tātad, lai rīkojoties ņemtu vērā vajadzības. Lai to panāktu, tiek izteikts lūgums. Lūgums padara iespējamu atvērtu rezultātu (ietver arī atteikuma iespēju) un līdz ar to ir pretstats prasībai. Tas aicina palikt dialogā tik ilgi, kamēr būs atrasti risinājumi, kuriem piekrīt visi iesaistītie

${ }^{35}$ M. Müller, Wertschätzende Kommunikationin der Grundschule: Einerlebnis-und sprach orientiertes Handbuch in neun Modulen Taschenbuch, Create Space Independent Publishing Platform, 2016. 
un kuri der visiem. Savukārt ar lūgumiem tiek rosināta brīvprātība un patiesums. Lūgumus var atpazīt pēc šādām četrām pazīmēm:

- lūgumi tiek formulēti pozitīvi. Tiek teikts tas, ko vēlamies, piemēram, "lūdzu esi precīzs", netiek teikts tas, ko negribam, piemēram, "lūdzu neesi neprecīzs";

- lūgumi tiek formulēti rīcības valodā. Lūgumu ir iespējams izpildīi šeit un tagad, piemēram, "vai tu piekrīti tam, ka nākamreiz mani īszin̄ā informēsi par kavēšanos?”. Prasības nevajadzētu formulēt, piemēram, "apsoli man, ka nekad vairs nekavēsi";

- lūgumi tiek izteikti skaidri un konkrēti, piemēram, "vai vēlies novilkt mēteli?". Ieteicams izvairīties no neskaidriem formulējumiem, piemēram, "atslābsti";

- $\quad$ lūgumā tiek pārjautāts, vai otrs ir gatavs lūgumu izpildīt, piemēram, "atsūti īsziņu. Labi?’. Tās nav tikai prasības, piemēram, "atsūti īsziņu”’36.

Analizējot cienošas komunikācijas modeḷa izmantošanu jebkurā komunikācijā, Meriona Millere (Marion Müller) uzsver, ka tikai zināšanas par to, kā darbojas cienoša komunikācija, vēl nenozīmē, ka vecāki to prot izmantot. Tāpēc nepieciešams vingrināties, lai zināšanas integrētu savā rīcībā un tādējādi stiprinātu un attīstītu cienošas komunikācijas prasmi ǵimenes dzīvesdarbībā. Lai zināšanas un prasmes varētu izmantot ikdienā, ir nepieciešamas cienošas aktivitātes, kuras bērniem un vecākiem būtu efektīvas. Ja gímenes locekḷi savstarpēji piedzīvo cienošu izturēšanos, noturīgi tiek aktivizēta autentiskā gatavība sadarboties, iesaistīties un cienīt vienam otru ${ }^{37}$.

\section{Nobeigums}

Pedagog̣ijas zinātne ir iesaistījusies bērnības izpētē, lai veidotu savu zinātnisko redzējumu par nepieciešamību konstruēt pieaugušo domāšanas veidu, virzot audzināšanas diskursu no dominantes model̦a uz bērncentrētu sadarbības modeli, kurā katrs atpazīst savas vajadzības un tās tiek apmierinātas. Bērna attīstības un bērnības saturs ir cieši saistīti ar attiecību kvalitāti ǵimenē, un, ja tajā dominē dominantes komunikācija vardarbīgs pasaules redzējums, bērns to nostiprina; ja dominē cienoša komunikācija, bērns interiorizē šo modeli. Tāpēc var apgalvot, ka audzināšanas satura viena no komponentēm ir vecāku-bērnu komunikācija, kuras pamatā ir gan pieaugušo, gan bērnu vajadzību atpazīšana un apmierināšana. Tādējādi var secināt, ka audzināšana kā komunikācija ir attiecību celtniecības māksla (arhitektūra) bērnībā, kas, veidojot visu bērnības saturu, nosaka visu attiecību plānojumu cilvēka tālākajā dzīvesdarbības laiktelpā.

Cienošas komunikācijas modelī komunikācija ir process, kurā komunikācijas partneri pārmaiņus ieklausās, atbild un izsakās. Līdz ar to process veido

\footnotetext{
${ }^{36}$ M. Müller, Wertschätzende Kommunikationin der Grundschule: Einerlebnis-und sprach orientiertes Handbuch in neun Modulen Taschenbuch, Create Space Independent Publishing Platform, 2016.

37 Ibid.
} 
komunikācijas ietvaru, savukārt četri soḷi (novērošana, izjūtas, vajadzības un lūgums) un empātija (fokuss uz izjūtām un vajadzībām) veido komunikācijas procesa saturu. Šādā komunikācijā partneri sociālās lomas (informācijas sūtītājs, saṇēmējs) izjūt kā saskanīgas un cita citu papildinošas, tāpēc šāda komunikācija ir efektīva audzināšanā.

Cienoša komunikācija audzināšanā apmierina gan pieaugušā, gan bērna vajadzības, tādējādi, nosakot bērnības emocionālo fonu. Tikai tad, kad vecāki spēs atpazìt, pieņemt un apmierināt savas vajadzības, viņi spēs atpazìt bērna vajadzības. Tādējādi, ja vecāki atpazīst savas vajadzības un izjūtas, viniem veidojas izpratne par sevi un veselīga pašapziņa, kas veicina bērna rīcībspēju attīstību. Izmantojot šādu komunikācijas modeli, tiek veicināta līdztiesība un līdzestība komunikācijā, jo palīdz ǵimenes locekḷiem konstruktīvi komunicēt kopīgajā un sabiedriskajā dz̄ivesdarbības laiktelpā.

Nobeigumā gribētos Hermaņa Šmica (Hermann Schmitz) atziṇu par miesas un ķermeņa klātbūtnes noklusēšanu cilvēku dzīvē un zinātnē "Tiešas miesas fenomenologijas ceḷā stājas nevis būtiskas izteiksmes grūtības, bet gan par saprātu lepno filosofu negribēšana" ${ }^{38}$ vispārināt uz komunikāciju audzināšanā. Iespējams, autora minētā pieaugušo lepnība par savu saprātu l̦auj/liek izvēlēties dominantes komunikāciju ar bērniem vai arī, gluži otrādi, - nezināšana un neizpratne par bērnu klātbūšanu viņu, pieaugušo, laiktelpā liedz atzīt sev neizprotamo un mainīt komunikācijas veidu ar bērniem, un tāpēc uzturēt dominantes komunikāciju.

\section{Summary}

The value of the child and childhood in personal development, cultural as well as political and economic aspects represent a current topic. Childhood is a social structure, within which personality is developed. Additionally, family upbringing characterized by continuity and durability is a crucial prerequisite for personality formation. Therefore, the issues related to the essence of childhood and upbringing maintain their topicality within Postmodernism. Thinking pluralism characteristic to the Postmodern spacetime promotes the child-centred approach and family upbringing liberalization trends lead to the necessity for pedagogy to search for theoretical and practical guidelines. The article analyzes a child-oriented family upbringing research perspective, which is based on respectful communication principles in building the childhood content.

The article puts forward the conclusions that, firstly, in the framework of respectful communication model, communication is a process, within which communication partners alternately listen, respond and express themselves. Therefore, the process builds the communication framework, in turn, the four stages (observation, feelings, needs and request) make up the contents of the communication process. Communication is effective, if communication partners view the social roles (information sender, recipient) as coherent and complementary. Secondly, respectful communication within the upbringing meets the needs of both child and adult, and predetermines the emotional background of childhood. Thirdly, parents are able to recognize the child's needs only when they are able to recognize, accept and meet their own needs. Therefore, recognition of needs and feelings forms the basis for parents' understanding of themselves and constructing

${ }^{38}$ H. Schmitz, Der Leib, Berlin, Walter de Gruyter GmbH \& Co, 2011, p. 173. 
a self-awareness, which promote the development of an action-oriented child. Fourthly, the respectful communication model promotes equality and consent in communication, as it helps family members to constructively communicate within the common spacetime.

Keywords: family upbringing, childhood, child-centered approach, respectful communication.

\section{Informācija par autori}

Dace Medne 2010. gadā LU Pedagoǵijas, psihologijas un mākslas fakultātē ieguvusi pedagoǵijas doktora zinātnisko grādu sociālajā pedagoǵijā. J. Vītola Latvijas Mūzikas akadēmijas Vispārējās izglītības mūzikas skolotāju katedras asociētā profesore. Latvijas Profesionālo psihologu asociācijas, Latvijas Smilšu spēles terapijas biedrības, IAHE (The International Academy for the Humanization of Education) biedre. Zinātnisko interešu loku veido audzināšana gimenē, bērncentrēta audzināšana un cienoša komunikācija gimenē. E-pasts: dace.medne@hotmail.com. 